\title{
ABOUT THE ASPECTS AND ROLES OF PHRASEMES IN KOSZTOLÁNYI'S SKYLARK (1924)
}

\author{
KATALIN BUCSICS \\ Eötvös Loránd University \\ E-mail: bucsics_katalin@hotmail.com
}

\begin{abstract}
In this essay I examine the ways in which language functions both as a means of preserving the past and as a marker of change by examining the significance of phrasemes in the novel Pacsirta (Skylark) by Hungarian author Dezső Kosztolányi. In part by examining the ways in which the English and German translators of the novel dealt with the complexities posed by the historically and culturally embedded nature of language, I explore the complex and at times contradictory functions of language in the novel. Kosztolányi's use of phrasemes in Pacsirta, I argue, exemplifies several of his theoretical ideas about language itself and the roles of language in the mediation of the past.
\end{abstract}

Keywords: Dezső Kosztolányi, Hungarian literature, phrasemes, proverbs, Humboldt, translation theory, linguistics

Dezső Kosztolányi's second novel, Pacsirta (Skylark, translated into English by Richard Aczel), ${ }^{1}$ met with interest among linguists at a time when the reception of his oeuvre was weak in some ways. ${ }^{2}$ Writing on Kosztolányi and the Hungarian language one linguist referred to Pacsirta as one of the most telling works of the author in this context (Deme, 1960). Another offered a deep analysis of linguistic forms in the novel, enumerating stylistic elements in its text (Horváth, 1959) and demonstrating the highly masterful linguistic elaborateness of the work. She even rebuked a former literary historian for having completely misinterpreted the novel by neglecting its essence, namely the structure of its text (Horváth, 1959, 332).

Some decades later, however, a literary historian wrote an article entitled Kosztolányi on Language. As Mihály Szegedy-Maszák claims, Pacsirta "interprets the world as a confused interaction of language games. Pacsirta's own let- 
ter, the dream [of her father - KB] as well as the card game in the casino or the menu card in the restaurant represent distinct language games." (SzegedyMaszák, 1998a, 264) ${ }^{3}$ From that time on, Pacsirta proved to be a rich source for literary interpretations focused on language, even in the recent past. A monograph written by Katalin Szitár entitled A prózanyelv Kosztolányinál [“Kosztolányi’s Prose"] (Szitár, 2000) and a detailed study by Tibor Bónus entitled A csúf másik ["The Ugly Other"] (Bónus, 2006) can be mentioned as significant examples of works by authors who also used the methods of semiology, deconstruction, literary anthropology.

As was noted in the interpretations of the novel by linguists since very early on, the novel itself brings its own medium into the foreground. One must also note that in this context almost every study emphasizes the characters' distinctive use of language in Pacsirta. Writing on the role of lexical items in the novel, Mária Horváth was the first to note that Latin proverbs and quotations, special terms of duel vocabulary, and those of pharmacology and of genealogy had been used by certain characters in the story (Horváth, 1959, 355). As László Deme observed, "the masterly choice of words" by Kosztolányi creates the impression that each character can be identified by his or her speech (Deme, 1960). These linguists referred to the same phenomenon which is later (already in connection with narratological characteristics of the novel) described by Erzsébet Juhász as the "alien word” (Juhász, 1995), by Mihály Szegedy-Maszák (after Wittgenstein) as "language games", and by Tibor Bónus as "alien discourses" i.e. "dialogic multilingualism” (Bónus, 2006). Interestingly enough, each of these studies concentrated on the level of lexemes. The present analysis would like to accentuate another aspect by pointing out the remarkable presence of phrasemes, not only as part of the characters' interactions but also throughout the whole novel. As I demonstrate by citing several examples, these "small forms", which have already been mentioned in the secondary literature but were not given much importance in the existing analyses, play a special role as structural and historical phenomena in the text by creating deeper textual interrelations.

Another reason why the level of phrasemes is relevant to analyses of Kosztolányi's prose is that the author himself was highly interested in this linguistic phenomenon (as he was in language itself). ${ }^{4}$ In the early 1920s, before he had adopted the later linguistic purism which found expression in his pamphlet-like and manifesto-like articles, ${ }^{5}$ he reviewed a book entitled Szokásmondások ("Proverbs and Sayings") on the etymological genesis of old Hungarian sayings. In this work, the linguist and folklorist Manó Kertész “excavates” old measurements, professions, tools, etc. as elements of phrasemes. In the introduction to the book he refers to these materials as cultural monuments. In the review Kosztolányi makes the following assertion: "We, inheriting the language from our great-great grandfathers, speak it like children do. We remember many things, yet it is the 
language that remembers everything latently. It absorbs the forgotten habits of the past and they covertly lurk forth in it” (Kosztolányi, 2002a, 36). ${ }^{6}$ Accordingly, proverbs seem to preserve tradition even against the permanent change of meaning, which, in contrast, significantly affects language. As Kosztolányi wrote in an essay many years later, "Oh, my dear fellow, what an eventful life words do live. You can't find one of them that would mean exactly the same thing in 1933 as it meant in 1900" (Kosztolányi, 2002b, 206)

In the same year in which Manó Kertész’s book was published, Kosztolányi started to write his novel, Pacsirta. The plot is set in 1899 and the novel depicts a world that at the time of its portrayal belonged already to the realm of imagination, namely the Austro-Hungarian Monarchy. As many interpreters have noted, Pacsirta is wholly about the past, as is reflected even by the profession of the protagonist. It is worth noting that the work of the archivist described in the novel is quite akin to the task of the linguist portrayed by Kosztolányi in his review of Szokásmondások, as both of them burrow into the past in search of their materials. "It was here he came alive; here in the past." $(24)^{8}$ So, if it is true that "[p]hrasemes tend to absorb and accumulate cultural elements" and they bind so to cultural memory (Piirainen, 2007, 217), then one could claim that proverbs and certain idioms in the novel represent (not as signified but as signifier) the past itself, as Pacsirta depicts a world in which time has stopped. However, the sayings, i.e. proverbs, in the text do not, in the historical sense, really belong to the common past with the Austrian Empire. Rather, some of them, perhaps not accidentally, have German equivalents or sources. One can demonstrate this simply by referring to the four German translations of Pacsirta, ${ }^{9}$ as well as by citing Manó Kertész’s etymological derivations (Kertész, 1985). Nevertheless, one notes that in the English translation of the novel almost each of these culturally specific phrasemes was omitted or replaced. Let me enumerate some telling examples below.

When after a long time Bálint Környey, the commander in chief of the local fire brigade and a prominent figure of the town, "spotted Ákos, the dear old friend and companion of his youth" (50), he called out in surprise: "This is a turn-up for the books". When later, thanks to his promptings, Vajkay appeared at the weekly revelry again after years of not having attended, Környey rebuked his companion with the following words: "You've a lot to answer for" (129). The first case is based on a nonsense saying: "Fel kell írni a kéménybe fekete krétával", which means literally: "it should be written onto the chimney wall with black chalk". The same saying exists in German as well, so almost all of the German translations use this idiom. ${ }^{10}$ Richard Aczel, in contrast, had to replace it at the same level with an English idiom: "This is a turn-up for the books" (50). In the second case the Hungarian idiom "Sok van a rovásodon” re- 
minds one of an old habit, as does the German "er hat zuviel auf dem Kerbholz."11 (cf. Kertész, 1985, 163). The English version, however, retains its figurative meaning only: "You've a lot to answer for" (129). ${ }^{12}$ Even if there are some idioms which have a German equivalent, most of the phrasemes are more culture-specific, so they remain, even literally, only more or less translatable. (Not surprising if one knows that Kosztolányi, as his essays confirm, mainly adopted Humboldt's conception of linguistic and cultural relativism (Bengi, 2012, 198-217)). Accordingly, the most eminent example cannot be found in Richard Aczel's English translation at all. The scene in which Ákos Vajkay eats a delicious meal in the local restaurant comes to a conclusion with an old Hungarian idiom that actually expresses how satisfied he is: "Vérré vált benne mint barátban a lencse” (Kosztolányi, 2013, 179). The German texts, which retain literal and figurative meanings, ${ }^{13}$ still lack the folk etymology that the original was based on, for there is also an anecdote about the misheard Latin words: vere valet (Szemerkényi, 2009, 115).

To conclude, Pacsirta contains more than thirty phrasemes, the abovementioned of which can be seen as indicators of language as a medium of cultural memory. In this context their historical meaning proved important. Norrick's following explanation about the twofold relation to the tradition of proverbs is true of idioms as well: "On the one hand, proverbs in general are traditional by virtue of their being items of folklore. In this sense, as we have just seen, traditionality amounts to common use in a linguistic community or in one of its lectal groups over a period of time, say more than one generation. On the other hand, any given proverb may be considered traditional or not on the basis of its content, especially if it is cast in rustic imagery, i. e. if it describes a pre-Industrial Revolution scene, and/or contains archaisms." ${ }^{14}$ (Norrick, 1985, 40)

The past presented in the novel is hardly judged in a one-sided manner. Its values and tradition(s) are questioned by many ironic scenes and characters in the story, which seems to reflect the fact that the world of the Monarchy was exhausted and decaying by 1899. The approach of including items from the level of phrasemes is also able to mirror this aspect and it does so to such an extent that even the opposite of the previously noted quality of phrasemes can be registered: total inadequacy and meaninglessness.

The most striking presence of proverbs and sayings in the novel can be identified in the scenes in which Szunyogh, the alcoholic Latin teacher of the local secondary school, uses many Latin sentences. The drunken man "could speak only Latin, above all through quotations from the classics." (191) However, it is worth mentioning that the only classical quotation he utters throughout the novel is a paraphrase of a line from Vergil's Aeneis Post tot discrimina rerum (Vergil: Aeneid I, 204-205) (197). (In the early manuscript of the novel a citation from Juvenal's Satires could 
also be found (Kosztolányi, 2013, 470). ${ }^{15}$ In addition to the above examples, he quotes one line from The Bible: Etiam si omnes, ego non (Mat. 26:33) (191) and a maxim from Jean de Santeul (1630-1697) “Castigat ridendo mores” (192). He also uses Si tacuisses philosophus mansisses, which is actually a common Latin saying, though it can be regarded as a quotation, for as Norrick puts it: "A speaker who uses a proverb falls back on the traditional store of performed utterances. Seen this way, utterances of proverbs are acts of quoting.” (Norrick, 1985, 26). Yet as the teacher character really does not utter any word in Hungarian throughout the novel (cf. the scene in which he orders even his schnapps at the restaurant in this ancient language: aquam vitae, aquam vitae (191)), his speech is actually a "conglomeration" of Latin citations. The fact that the sentences are uttered in a foreign language affirms the feeling that the "other voices" entirely incorporate Szunyogh's own speech. Thus the "ready-made utterance" instead of an "original utterance" (Norrick, 1985, 25) has a negative effect in this context. Moreover, the use of the quotations illustrates a knowledge less active than an "enormous erudition [...] submerged beneath a sea of wine and schnapps" (73). This is so true that the proverbs and sayings used by this character prove to be completely meaningless in this respect. Given that Szunyogh addresses the Panthers, his fellows, most of whom do not know Latin, ${ }^{16}$ the conversation is something of a monologue as the recipients do not understand his quotations. On the other hand, the teacher's wasted life and ambition (48) can ironically attest to the inefficiency of the sayings and proverbs; they simply lose one of their main roles, the didactic tone. ${ }^{17}$ " [S]peakers use proverbs to direct and convince hearers [and] hearers interpret (even non-didactically intended) proverbs as prescriptive moral rules or as directive warnings.” (Norrick, 1985, 42)

On the contrary, the archivist Ákos Vajkay wants to believe in the existence of "eternal verities". He needs proverbial wisdom as he expects every book to be a guide for life: ${ }^{18}$ "he preferred stimulating, edifying books which elucidated some moral truth or the interconnections between otherwise meaningless or incomprehensible facts. Truths like 'hard work is always rewarded' or 'evil never goes unpunished'; books that rock one in the lap of the comforting illusion that no one suffers undeservingly in this world, nor dies of stomach cancer without due cause." (86-87) Still the destiny of his spinster daughter convinces him that "[t]here was no justice in the world, no justice anywhere. Everything was meaningless." (125) He and his wife meet "the fledgling provincial poet” whose father's story forced Vajkay again to draw a bitter conclusion: "How children suffer for their parents, and parents for their children.” (106) Consequently, eternal verities and moral rules are obviously rewritten by life as they seem to be ironically understood, as the truths Vajkay prefers are mostly worn-out clichés of penny-books. A parody of wisdom and didacticism can be detected in the "pseudophrasemes" (Eismann, 2007, 327) of the Panthers and Feri Füzes: "Those who were sick twice had had a better time than those who were sick only once” (194); 
"what had worked once would work twice” (192); "just like everyone else, Lajos Kossuth has his good points and his bad points." (69)

As Norrick notes "Jolles [...] objects [...] [the] prescriptive didactic tendency. [...] He insists strenuously that proverb content is directed toward past experience rather than to future behaviour.” (Norrick, 1985, 41) Kosztolányi, who preferred the indirect instead of the direct meaning in literary works, would have likely shared the opinion of the Dutch folklorist and linguist about proverbs (Norrick, 1985, 41). In an essay on literature entitled “Why do we write?” Kosztolányi argues in support of the opposite of what Ákos Vajkay requires from books: "Every work behind which there is not all of life remains meaningless. What to twaddle about if one understands life? The real poet does not understand life and writes only to understand it through the act of writing (and not, like a teacher, to make people understand it)." (Kosztolányi, 2002c, 397) ${ }^{19}$ The refusal of the didactic tone can be confirmed by the fact that, in a kind of rejection of a still dominant literary tradition, Pacsirta possesses a circular narrative structure instead of having a developing and simply linear plot (See Szegedy-Maszák, 1998b, 87).

Jolles, who emphasizes the importance of past experience in proverbs, analysed their formal aspects in a book entitled Einfache Formen: Legende, Sage, Mythe, Rätsel, Spruch, Kasus, Memorabile, Märchen, Witz. The genres in the title, he argues, are "small genres" or "short forms" the smallest literary (pre)categories in language. (Jolles, 1968, 150-170) The artistic potential of phrasemes seems to reside not only in their figurativeness yet in their state as text and therefore their manifold nature of "intertextuality" (See Piirainen referring H. Burger 2007, 209). "One could go so far as to say that there is a 'story' behind every proverb, and it is usually a sizable task to deal with just one text in this diachronic and semantic fashion.” (Mieder, 2007, 401) ${ }^{20}$

In this section I would like to analyse phrasemes in the novel as text within text concentrating on the interaction between them. To assert that this relation is not a supposition made by the present study but it does intentionally exist in Pacsirta we have many reasons. Hardly insignificant in this context is that Kosztolányi in an homage announced Péter Pázmány (1570-1637) a kind of predecessor, more close to him than any other Hungarian prose writers. (Kosztolányi, 1976, 42, 48) Kosztolányi described how fascinated he had been when reading the whole oeuvre of the famous catholic preacher (Kosztolányi, 2002d, 340), a collection of sermons and disputations. He praised the language of such an author whose works are considered to be one of the main sources of the phraseological collections and scrutinies. Pázmány played an undoubtedly great role in the bequeathing of old (Hungarian) proverbs. (Tolnai, 1910, 22) ${ }^{21}$ It is quite likely then that, as an heir to this tradition, Kosztolányi thought phrasemes were the essential elements of prose. 
Furthermore, an author who has, like Kosztolányi, written so many times about the importance of structure and who has highly appreciated narrative compactness of literary works, could presumably be fascinated by proverbs and idioms as extraordinary dense stories. That is convincingly proven by some proverbs in the novel that seem to have deeper connections with different elements and levels of the narrative thus improving the complexity of the text. (See Eismann, 2007, 325)

A paraphrase of a Hungarian saying can serve as a telling example for a kind of symbiosis of small form and great narrative. After Pacsirta's parents arrived home from the railway station where they had said goodbye to their daughter who had left for a holiday, we can see them in her room quite regretfully. As the scene is set on Friday and the father wants to console his already crying wife he utters the following words: “Aki pénteken sír, az vasárnap nevet.” (Kosztolányi, 2013, 81) The English translation of the phrase is literally the same: "Friday's tears are Sunday's laughter.” (29) It is actually the reversed version of the original Hungarian saying: „Ha pénteken jókedved van, vasárnap sírsz”; „Pénteki öröm, vasárnapi üröm” (Szemerkényi, 2009, 1140) (literally: 'If you laugh on Friday, you will cry on Sunday'). There is evidence that the change was deliberate and not a misprint, as each earlier version of the novel, including the existing manuscript, contains similarly the reverse of the original. ${ }^{22}$ Moreover, the already mentioned study on proverbs by Vilmos Tolnai, that Kosztolányi read in the same year when he began to write Pacsirta, eventually contains this saying (Tolnai, 1910, 33). Still the change seems quite motivated if one pays attention to the context and is aware of the nature of Vajkay's character. His only effort is actually to suppress the tragedy of their life by deluding himself and his family about the opposite. This impression is confirmed by the short dialogue it is used in: "'Whatever will we do without her?' Ákos made no reply. He never spoke much, but felt and thought all the more." then "'And we'll laugh too, Mother, just you see,' he said without a trace of conviction, and disappeared into the dining room.” (29)

Here we could see how a set phrase had been changed for the sake of the novel's meaning; the next examples then present how a properly chosen phraseme can deepen the impact made by the main elements of the story.

The central character, Pacsirta, in a letter tells her parents about how she is spending her holiday at her relatives' home in the plain of Tarkő. She describes her aged uncle and adds that he still likes playing jokes as he has said to her the same even then what he used to say during her childhood: "Never fear Skylark dear, Uncle Béla’s here.” (119) Although the English version by Richard Aczel splendidly grasped the manner of the sentence yet his translation misses a likely important element. The original idiom actually contains the word "eyesight" ["Ne félj, míg engem látsz"]: a sense through which Pacsirta’s ugliness is only perceivable. The fact that her uncle's "sweet humour" is hardly innocent (even if unintentional $)^{23}$ can be confirmed by another idiom he uses when he gets to know 
how Pacsirta's parents worry about her: “A bad penny...," he says (119). As this idiom refers to "someone or somebody undesirable" 24 it can easily be read as a mise en abyme of the novel's central theme in a condensed figurative form: the tragedy of the spinster as well as her parents. Neither a marriage nor a railway accident could "guarantee" the absence of their ugly and oppressive daughter. ${ }^{25}$ As during her break-away at Tarkő, even in her absence almost every object reminds her parents of her perpetual presence.

Similarly, Pacsirta, after her arrival, is handing a photograph of her and the relatives over to her parents with the following words: “Guess who!” (212). Yet the Hungarian original version contains actually the first words of a rhyme "Itt vagyok ragyogok" (Kosztolányi, 2013, 519), whose second half remains implicit in the novel yet seems to be hardly irrelevant: "mint a fekete szurok". The whole saying translated literally into English is as follows: 'Here I glow - just like the black pitch'. This paradox (or nonsense) can be seen again as an idiomatic formulation of Pacsirta's fate.

These examples illustrate how the phrasemes can deepen the meaning and the structural complexity of the novel.

Interestingly, even the inverse of such a relation has been detected in the novel. One interpreter remarked that the beginning of the novel evokes the following well-known French proverb: Partir, c'est mourir un peu (Bónus, 2006, 41). ${ }^{26}$ As in the opening lines of the third chapter can be read: "When people go away they vanish, turn to nothing, stop being. They live only in memories, haunting the imagination. We know they go on being somewhere else, but no longer see them, just as we no longer see those who have already passed away.” (17) The text in this part does not lack further elements of such a figurative sequence: "They stared dumbly into space like the speechless victims of some sudden loss, their eyes still hankering after the spot where they had last seen her." [my accent. KB] (17) and after "They hung their heads and stared at the gravel on the track as mournfully as at an expectedly and hastily filled grave." [my accent. KB] (18).

Indeed, there are further narrative sections in the novel that can recall certain idioms or proverbs for the reader. In the very beginning of the fifth chapter the following can be read: "Sárszeg is a tiny dot on the map. [...] Most people have either never heard of it, or mention it with disdain. But every Sunday morning, in the clear blue sky before the Church of St. Stephen, the good Lord hovers above the town, invisible and merciful, righteous and terrible, ever present and everywhere the same, be it in Sárszeg or in Budapest, in Paris or New York.” (59) This part of the text could even be perceived as an elaborated negation of the idiom: behind God's back. A very similar, yet in the translation hardly perceptible, allusion of an idiom could be identified in the opening phrase of chapter 7: “And as for Thursday... Well, Thursday was simply Thursday. A Thursday 
was no ordinary day. [...] For Thursday was the day of the shindig.” (127) There is a Hungarian idiom "Csütörtököt mond” [literally: 'To say Thursday'], which actually means "to be ruined" or "to fail". This supposition as a possible connotation may seem less exaggerated if one reads about the "shindig": "[t]he women of Sárszeg looked forward to these Thursdays with trepidation. Their husbands would stumble home at dawn, or later still, and all day long they'd be surely, red-eyed and thoroughly sick." (127) As well as on Thursdays a group called "the Panthers" would flock together: "[T]he Panthers' Table had been formed some twenty years before, with the not unworthy aim of popularizing the consumption of alcohol and promoting gentlemanly friendship. The Panthers were expected to drink daily and diligently, whether they could hold their drink or not. [...] Many more had fallen by the wayside, collapsing from chronic alcohol poisoning and cirrhosis of the liver, which was how most men in Sárszeg met their end.” (49) Obviously, the intention of such Thursday evenings is not less than being spoiled. Nevertheless, the night of the shindig prepares the climax of the novel as well in the next chapter still during the same night signaled by the Ákos Vajkay's outburst. It is then for the first time when he utters to his wife that they could not love their daughter, Pacsirta, because of her ugliness (167).

As I have shown, Kosztolányi's novel presents antagonistic aspects of proverbs and idioms. Phrasemes used in Pacsirta's world are able to illustrate the erosion of communication as well as the exhaustion of language, while proverbs and idioms used on a meta-level for describing the world of Pacsirta prove on the one hand the historical richness of language and on the other its artistic potential. Kosztolányi was well aware of the Janus-faced nature of language, which changes and preserves simultaneously. The focus on the level of phrasemes in Pacsirta could show how the greatness of this novel resides mainly in the manner in which it includes and unites different values (even literary historical paradigms), therefore permitting multiple simultaneous and divergent interpretations.

\section{Notes}

1 First published in 1924. Dezső Kosztolányi: Pacsirta. Budapest: Athenaeum, 1924. In English: Dezső Kosztolányi: Skylark. Trans. Richard Aczel; Introd. by Péter Esterházy. London: Chatto \& Windus, 1993.

2 One can even talk about a suppression by the ideology of the 1950s. As it has resulted in the highly controversial book on Kosztolányi’s oeuvre by Ágnes Heller. "The strongly moral approach goes together with an emphasis on biography, Kosztolányi’s works are examined as documents that illustrate the value system of the author. Her perspective must have changed radically since the 1950s, when she failed to see that Kosztolányi had anticipated the loss of credibility of great narratives.” Mihály Szegedy-Maszák, Agnes Heller on Literature = Ethics and Heritage: Essays on the Philosophy of Agnes Heller, Ed. János Boros, Mihály Vajda, Pécs, Brambauer, 2007, 163-174. Especially: 163-166. 
3 [Translated by the author - KB] [“a regény különböző nyelvjátékok egymást zavaró kölcsönhatásaként értelmezi a világot. A címszereplő levele éppúgy önmagában zárt nyelvjáték, mint az álom, a kaszinói kártyajáték vagy a vendéglői étlap”.] In his recently published monograph on Kosztolányi a chapter analysing the language of the novel is titled: "Language Games". Mihály Szegedy-Maszák, Kosztolányi Dezső. Pozsony: Kalligram, 2010, 237-242.

4 He has written numerous essays (filling more volumes of his oeuvre) on language (i.e. its phenomena). His notion on language was quite complex yet sometimes paradox since as an artist his writings lack theoretical regularity and methodology.

5 For a detailed periodisation of his concept see László Bengi’s recent paper. László Bengi, Hagyomány és viszonylagosság. Kosztolányi nyelvfölfogásáról In: László Bengi: Elbeszélt halál. Kosztolányi-tanulmányok, Budapest: Ráció, 2012.

6 [Translated by the author - KB] [“Mi a nyelvünket, melyet ükapáinktól örököltünk, úgy beszéljük, mint a kisgyerekek. Sok mindenre nem emlékszünk. De a nyelv, rejtetten mindenre emlékszik. Az fölveszi magába a múlt elfelejtett szokásait, melyek tovább bujkálnak benne, homályosan."]

7 [Translated by the author - KB] [“Jaj, barátom, micsoda pályát futnak meg a szavak. Nincs olyan, amely 1933-ban pontosan azt jelentené, amit 1900-ban jelentett.”]

8 See also Kosztolányi, Szokásmondások, 51-52. (The page numbers in the text refer to the following edition: Dezső Kosztolányi, Skylark, Trans. Richard Aczel, with an introduction by Péter Esterházy, Budapest, London, New York: CEU Press, 1993.)

9 The following German editions were published from 1928 to 2007: Desider Kosztolányi, Lerche (Roman), Trans. Stefan J. Klein, Heidelberg: Merlin Verlag, 1928; Dezső Kosztolányi, Lerche (Roman), Trans. Klaus Schmuck, Rev. by Georg Harmat, Afterw. by Paul Kárpáti, Leipzig: Reclam, 1970 (1976: 2nd edition); Dezső Kosztolányi, Lerche (Roman), Trans. Heinrich Eisterer, Afterw. by Ilma Rakusa, Frankfurt M.: Suhrkamp Verlag, 2007; Dezső Kosztolányi, Lerche (Roman), Trans. Christina Viragh, Afterw. by Péter Esterházy, Zürich: Manesse Verlag, 2007.

10 "Das müssen wir ja mit schwarzer Kreide in den Schornstein schreiben.” (Trans. by Stephan J. Klein; Kosztolányi, 1928, 59); "Das muß man ja mit schwarzer Kreide in den Schornstein schreiben!” (Trans. by Klaus Schmuck; Kosztolányi, 40); “Das wird man in den Kamin schreiben müssen, mit schwarzer Kreide.” (Trans. by Christina Viragh; Kosztolányi, 2007a, 66); The only example in Heinrich Eisterer's translation keeps only the literary meaning by using another expression that, however, lacking the nonsense of the original's: "Den Tag müssen wir uns rot im Kalender anstreichen.” (Trans. Heinrich Eisterer; Kosztolányi, 2007b, 50.)

11 The idiom is based on the use of notch. Although there are idioms in English with "notch" they only refer to high or low 'quality' (top notch; take it up a notch; etc.).

12 About literal and figurative meaning (mostly of proverbs) see: Norrick Neal R., How proverbs mean: semantic studies in English proverbs. Berlin, New York: Mouton, 1985.

13 "Das Essen wurde in ihm zu Blut, wie im Mönch das Linsengericht." (SJK, 83); "Diesen Speisen würden ihn kräftigen, sich in Blut verwandeln wie in einem Mönch das Linsengericht." (KSch, 55); "Es hatte ihm ausgezeichnet gemundet." (E, 70); "Die Speisen in ihm wurden zu Blut wie im Klosterbruder die Linsen.” (ChV, 94).

14 However the referred literature here is mainly on proverbs as the experts point out, many characteristics of proverbs, sayings and idioms are common. That leads even to a kind of terminological fuzziness: "When considering the open boundaries of the subject area of phraseology, and its fuzziness concerning categories, it seems neither desirable nor possible to find an exhaustive classification or terminology.” See Burger, 2007, 15.

15 Dat veniam corvis, vexat censura columbis (Juvenal, Satires II, 63) 
16 They do not understand, they can only recognize Latin words. "Those versed in Latin shouted back at him: Vino veritas, old boy, vino veritas.” Skylark, 192.

17 The dominant role of the Latin culture in education is indeed unquestionable - almost at that time: "In Europe this began in the Middle Ages when Latin proverbs were used for translation exercises and to teach children moral precepts. [...] In fact, the developmental stage of fourth graders might be the perfect time to confront students with the character-building values of proverbial laws of life." (See Mieder, 2007, 406)

18 The genre "self-help books" described in the study of Mieder seems to require such type of reader like Vajkay. See Wolfgang Mieder: Proverbs and cultural units or items of folklore In Phraseologie/Phraseology. Ein Internationales Handbuch der zeitgenössischen Forschung/An International Handbook of Contemporary Research. Ed. Harald Burger, Dimitrij Dobrovol'skij, Peter Kühn, Neal R. Norrick. Berlin, New York: Walter de Gruyter, 2007, Vol. I., 405-406.

19 [Translated by the author - KB] ["Minden írás, mely mögött nincs az egész élet titka, értelmetlen. Mit fecseg az, aki érti az életet? Az igazi költő nem érti az életet, s azért ír, hogy az írással, mint tettel megértse. (Nem azért, hogy másokkal, mint valami tanítómester, megértesse.)”] See also Mihály Szegedy-Maszák, Kosztolányi Dezsö, 236.

20 See also: „The interrelationship of proverbs with other verbal folklore genres has been of great interest to folklorists in general and paremiologists in particular for a long time. Classical Greek and Latin writers commented on the obvious interrelationship between fables and proverbs, theorizing, as it were, about which of the genres came first” Ibid., 404.

21 This fact is also announced by Vilmos Tolnai whose work on proverbs, as a letter proves, has been surely read by Kosztolányi. (Dezső Kosztolányi, Levelek - Naplók. Ed. Pál Réz, Budapest: Osiris, 1998, 472-472)

22 The novel was published in the fiction column of a periodical in Budapest and of a newspaper in Kolozsvár in 1923. So it has actually three more or less distinct printed versions.

23 That seems to be hardly untouched by the influence of Sigmund Freud's notions. As several essays and letters prove, Kosztolányi knew his works well.

${ }^{24}$ Webster's Universal College Dictionary, Gramercy Books: New York, 1997. It is actually the "kernel" of a longer version: A bad penny always turns up. Norrick called kernel "the minimal recognizable unit” of a proverb. See Norrick, How proverbs mean, p. 45.

25 Every sign during the waiting for their daughter at the railway station seems to prove them that Pacsirta never comes home: so the terrific visions of the father as well as the "mysterious and obscure" doubts of the mother about her vanishing. See Skylark, 187, 189.

26 Kosztolányi has indeed a short story titled A bujdosó ['The Hider'] from the year 1912, which can be really read as a kind of elaboration of this proverb. Dezső Kosztolányi, A bujdosó In Dezső Kosztolányi: A léggömb elrepül. Ed. Pál Réz, Budapest: Szépirodalmi, 1981.

\section{References}

Bengi, László. 2012. Hagyomány és viszonylagosság. Kosztolányi nyelvfölfogásáról In László Bengi Elbeszélt halál. Kosztolányi-tanulmányok, Budapest: Ráció.

Bónus, Tibor. 2006. A csúf másik. A saját idegenségének irodalmi antropológiájáról. Kosztolányi Dezső: Pacsirta, Budapest: Ráció.

Burger, Harald. Dobrovol'skij, Dimitrij. Kühn, Peter and Norrick, Neal R. 2007. Phraseology: Subject area, terminology and research topics In Phraseologie/Phraseology. Ein Internationales Handbuch der zeitgenössischen Forschung/An International Handbook of Contemporary 
Research Ed. by Harald Burger, Dimitrij Dobrovol’skij, Peter Kühn, Neal R. Norrick Berlin, New York: Walter de Gruyter. Vol. I., 10-19.

Deme, László. 1960. Kosztolányi és a magyar nyelv (Születésének 75. évfordulójára) In Magyar Nyelvőr (84) 2 145-147.

Eismann, Wolfgang. 2007. Phraseme in Literarischen Texten In Phraseologie/Phraseology. Ein Internationales Handbuch der zeitgenössischen Forschung/An International Handbook of Contemporary Research Ed. by Harald Burger, Dimitrij Dobrovol'skij, Peter Kühn, Neal R. Norrick. Berlin, New York: Walter de Gruyter, Vol. I, 316-329.

Horváth, Mária. 1959. A nyelvi formák szerepe Kosztolányi prózájában. A Pacsirta címü regény elemzése Budapest: A Kiadói Főigazgatóság stilisztikai évkönyve, 330-407.

Jolles, André. 1968. Einfache Formen: Legende, Sage, Mythe, Rätsel, Sprüche... Tübingen: Max Niemeyer Verlag.

Juhász, Erzsébet. 1995. Hiány és többlet. A távolságtartások rendszere Kosztolányi Dezső Pacsirta címü regényében In: Üzenet No. 4-6, 222-227.

Kertész, Manó. 1985. Szokásmondások. Nyelvünk müvelődéstörténeti emlékei, Budapest: Helikon.

Kosztolányi, Dezső. 1924. Pacsirta, Budapest: Athenaeum.

Kosztolányi, Dezső. 1928. Lerche Trans. by Stephan J. Klein, Heidelberg: Merlin.

Kosztolányi, Dezső. 1976. Lerche Trans. by Klaus Schmuck, Afterw. by Paul Kárpáti, Contrib. Georg Harmat, Leipzig: Reclam [2 $2^{\text {nd }}$ ed.].

Kosztolányi, Dezső. 1976. Pázmány Péter In Látjátok feleim Ed. Pál Réz, Budapest: Szépirodalmi.

Kosztolányi, Dezső. 1981. A bujdosó In Dezső Kosztolányi A léggömb elrepül, Ed. Pál Réz, Budapest: Szépirodalmi.

Kosztolányi, Dezső. 1993. Skylark, Translated by Richard Aczel, with an introd. by Péter Esterházy, Budapest, London, New York: CEU Press, 1993.

Kosztolányi, Dezső. 1998. Levelek - Naplók Ed. by Pál Réz, Budapest: Osiris.

Kosztolányi, Dezső. 2002a. Szokásmondások In Dezső Kosztolányi Nyelv és lélek, Ed. Pál Réz, Budapest: Osiris [3rd ed.].

Kosztolányi, Dezső. 2002b. Párbeszéd In Nyelv és lélek Ed. Pál Réz, Budapest: Osiris [3rd ed.].

Kosztolányi, Dezső. 2002c. Miért írunk? In Nyelv és lélek Ed. Pál Réz, Budapest: Osiris [3rd ed.]

Kosztolányi, Dezső. 2002d. Paraszti és népies In Nyelv és lélek Ed. Pál Réz, Budapest: Osiris [3rd ed.]

Kosztolányi, Dezső. 2007a. Lerche Trans. by Christina Viragh, Afterw. Péter Esterházy, Zürich: Manesse Verlag.

Kosztolányi, Dezső. 2007b. Lerche Trans. by Heinrich Eisterer, Afterw. Ilma Rakusa, Frankfurt am Main: Suhrkamp.

Kosztolányi, Dezső. 2013. Pacsirta, Ed. Katalin Bucsics, Ildikó Józan. [Kosztolányi Dezső Összes Müvei. Kritikai kiadás], Pozsony: Kalligram [critical edition].

Mieder, Wolfgang. 2007. Proverbs and cultural units or items of folklore In Phraseologie/Phraseology. Ein Internationales Handbuch der zeitgenössischen Forschung/An International Handbook of Contemporary Research Ed. by Harald Burger, Dimitrij Dobrovol'skij, Peter Kühn, Neal R. Norrick. Berlin, New York: Walter de Gruyter, Vol. I, 394-414.

Norrick, Neal R. 1985. How proverbs mean: semantic studies in English proverbs. Berlin, New York: Mouton.

Piirainen, Elisabeth. 2007. Phrasemes from a cultural semiotic perspective In Phraseologie/Phraseology. Ein Internationales Handbuch der zeitgenössischen Forschung/An International Handbook of Contemporary Research. Ed. by Harald Burger, Dimitrij Dobrovol'skij, Peter Kühn, Neal R. Norrick. Berlin, New York: Walter de Gruyter, 2007, Vol. I., 208-219.

Szegedy-Maszák, Mihály. 1998a. Kosztolányi nyelvszemlélete In Tanulmányok Kosztolányi Dezsőről Ed. Ernő Kulcsár Szabó, Mihály Szegedy-Maszák, Budapest: Anonymus, 259-271 
Szegedy-Maszák, Mihály. 1998b. Körkörösség és transzcendencia a Pacsirtában In: Tanulmányok Kosztolányi Dezsőrőll. Ed. Ernő Kulcsár Szabó, Mihály Szegedy-Maszák, Budapest: Anonymus, 79-91.

Szegedy-Maszák, Mihály. 2007. Agnes Heller on Literature In Ethics and Heritage: Essays on the Philosophy of Agnes Heller Ed. János Boros, Mihály Vajda, Pécs, Brambauer, 163-174.

Szegedy-Maszák, Mihály. 2010. Kosztolányi Dezső Pozsony: Kalligram.

Szemerkényi, Ágnes. 2009. Szólások és közmondások, Budapest: Osiris.

Szitár, Katalin. 2000. A prózanyelv Kosztolányinál, Budapest: Asteriskos.

Tolnai, Vilmos. 1910. A szólásokról: adalék a szóláshasonlatok, szólásmódok és közmondások elméletéhez Budapest: Magyar Nyelvtudományi Társaság [A Magyar Nyelvtudományi Társaság Kiadványai, 12].

Webster's Universal College Dictionary, Gramercy Books: New York, 1997. 